\title{
Early physiological and biochemical responses of rice seedlings to low concentration of microcystin-LR
}

\author{
Catarina C. Azevedo · Joana Azevedo $\cdot$ Hugo Osório · Vitor Vasconcelos - Alexandre Campos
}

Abstract Microcystin-leucine and arginine (microcystinLR) is a cyanotoxin produced by cyanobacteria like Microcystis aeruginosa, and it's considered a threat to water quality, agriculture, and human health. Rice (Oryzasativa) is a plant of great importance in human food consumption and economy, with extensive use around the world. It is therefore important to assess the possible effects of using water contaminated with microcystin-LR to irrigate rice crops, in order to ensure a safe, high quality product to consumers. In this study, 12 and 20-day-old plants were exposed during 2 or 7 days to a $\mathrm{M}$. aeruginosa extract containing environmentally relevant microcystin-LR concentrations, 0.26-78 1g/L. Fresh and dry weight of roots and leaves, chlorophyll fluorescence, glutathione Stransferase and glutathione peroxidase activities, and protein identification by mass spectrometry through twodimensional gel electrophoresis from root and leaf tissues, were evaluated in order to gauge the plant's physiological condition and biochemical response after toxin exposure. Results obtained from plant biomass, chlorophyll fluorescence, and enzyme activity assays showed no significant differences between control and treatment groups. How- ever, proteomics data indicates that plants respond to $\mathrm{M}$. aeruginosa extract containing environmentally relevant microcystin-LR concentrations by changing their metabolism, responding differently to different toxin concentrations. Biological processes most affected were related to protein folding and stress response, protein biosynthesis, cell signalling and gene expression regulation, and energy and carbohydrate metabolism which may denote a toxic effect induced by $M$. aeruginosa extract and microcystin- LR. The implications of the metabolic alterations in plant physiology and growth require further elucidation.

Keywords Rice - Oryza sativa - Microcystin-LR . GPx $\cdot$ GST $\cdot$ Proteomics

\section{Introduction}

Cyanobacteria (blue-green algae) are photosynthetic prokaryotes. Some species are known to produce potent bioactive compounds. Cyanobacteria outbreaks are a frequent phenomenon, often associated with the deterioration of water quality (e.g. increased eutrophication) (Bibo et al. 2008; Saqrane et al. 2008). The release of cyanobacterial bioactive compounds and toxins leads to water contamination and increases the risk of animal and human expo- sure, thus constituting a major environmental hazard. The utilization of contaminated water in agriculture may pose additional risks concerning crop growth and production, and food safety

Microcystins (MCs) are the most frequent cyanobacterial toxins in freshwaters (Hitzfeld et al. 2000; Tyler et al. 2009; WHO 2003; Zhang et al. 2007). MCs are produced by species of the genera Microcystis, Anabaena, Planktothrix, Nostoc, Oscillatoria and Anabaenopsis (Dawson1998; Hitzfeld et al. 2000; Ibelings and Chorus 2007; Saqrane et al. 2008). These cyclic heptapeptides are specific inhibitors of the catalytic subunit of protein serine/ threonine phosphatases 1 and 2A (PP1, PP2A) (Hitzfeld et al. 2000; WHO 2003). The side chain of the unusual amino acid 3-amino-9-methoxy-2,6,8-trimethyl-10phe- nyldeca-4,6-diene acid (ADDA), and possibly the planar ring portion of the peptide, might be responsible for recognizing as well as inhibiting protein phosphatases, which makes these parts of the molecule essential for its biological activity. MCs have been also referred to as inducing of oxidative stress in animals and plants (Bibo et al. 2008; Crush et al. 2008; Dawson 1998; Saqrane et al. 2007, 2008; WHO 2003). Moreover, MCs possess tumourpromoting activity and may be important liver carcinogens (Dawson 1998; Hitzfeld et al. 2000). More than $80 \mathrm{MC}$ chemical congeners have been identified, being MC-LR one of the predominant variants, containing leucine and arginine as variable amino acids at positions 2 and 4, respectively (Ibelings and Chorus 2007; WHO 2003).

The toxic effects of MCs in plants have also been characterized. MCs have been associated with the inhibition of germination and growth of several agricultural and forage plants (Crush et al. 2008; El Khalloufi et al. 2011; Saqrane et al. 2008). MCs were shown to inhibit the nodulation of fava bean (Vicia faba) and alfalfa (Medicago sativa) (El Khalloufi et al. 2011; Lahrouni et al. 2012). This condition may have implications in nitrogen uptake and development of leguminous plants. Alterations in root architecture and development have been reported for tissue-cultured common reed (Phragmites australis) challenged with $0.5-40 \mathrm{1g} / \mathrm{mL}$ MC-LR. These effects may be attributed to the activity of MC-LR on microtubule organization (Máthé et al. 2009). This work underlines the dose and time effects of exposure to the toxin. For instance, 2 day exposure to $10-401 \mathrm{~g} / \mathrm{ml}$ MC-LR caused inhibition of mitosis in roots of common reed (Phragmites australis). However, prolonged exposure (20 days) 
stimulated or inhibited mitosis in plants according to the toxin concentration, $0.1-5$ or $20-40 \quad 1 \mathrm{~g} / \mathrm{ml}$ MC-LR, respectively (Máthé et al. 2009).

Research has also highlighted that plants may take up and accumulate MCs. For instance, application of $2.1 \mathrm{mg} / \mathrm{L} \mathrm{MCs}$ for 15 days to ryegrass, clover, rapeseed, and lettuce plants led to the accumulation of $0.2-1.45 \mathrm{mg} / \mathrm{kg}$ toxin (dry weight, DW) in the root system (Crush et al. 2008). Moreover, Peuthert et al. (2007) reported average bioconcentration factors (BCFs) for MCs of 3.6 and 8.4, in shoots and roots respectively, from 11 agricultural species. The presence of MCs in the leaves of crop plants is consistent with the hypothesis of the presence of a root-to-shoot transport mechanism for MCs (Peuthert et al. 2007). The results also suggest that $\mathrm{MCs}$ accumulation in shoots, roots and leaves is time and concentration dependent (Peuthert et al. 2007; Saqrane et al. 2007).

Furthermore, data gathered regarding chlorophyll content, PSII activity, lipid peroxidation and the antioxidantresponse enzymes glutathione-S-transferase, glutathione peroxidase, and glutathione reductase provided evidence that photosynthesis and oxidative stress play a primary role in MC mediated plant toxicity and growth impairment (Saqrane et al. 2009; Peuthert et al. 2007; Pflugmacher et al. 2007). In addition to these, other molecular effects have been reported. Total activity of protein phosphatase was reduced in alfalfa plants after exposure to $5 \mathrm{~g} / \mathrm{L} \mathrm{MC}$ LR, MC-LW or cyanobacterial cell extracts containing equal concentration of MC-LR. This enzyme activity was followed by a MC-LW specific induction of MsPP1c and the MsPPle gene transcripts (Peuthert et al. 2008). Isoenzyme specific single-stranded DNA (ssDNase) and double- stranded DNA (dsDNase) cleaving activities were reported in root tip meristematic cells of Phragmites australis exposed for up to 20 days to MC-LR (0.5-40 $1 \mathrm{~g} / \mathrm{mL}$ ). Enzyme activity was consistent with the early induction of chromatin condensation and the subsequent occurrence of necrotic cell death providing evidence for the role of these enzymes in MC induced programmed cell death (Jámbrik et al. 2011).

Semi-aquatic cultures may be among the most susceptible to cyanotoxin exposure. In this regard, MCs were detected in water chestnuts and rice grains produced at Lake Tai in China, frequently contaminated with heavy cyanobacterial blooms (Chen et al. 2012; Xiao et al. 2009). Rice is the most important staple crop in the world; however, little data has been reported regarding the effects of cyanotoxins in this culture. Chen et al. (2012) have recently reported that high MC-LR concentration (C2.0 1g/mL) affects rice root morphogenesis by inhibiting root elongation, crown root formation, and lateral root development from primordia. Treatment with high concentrations of MC-LR stimulated the production of reactive oxygen species (ROS) and inhibited the production of nitric oxide (NO) in rice roots. In contrast, lower toxin concentrations (0-200.0 $\mathbf{1 g} / \mathrm{L})$ did not affect rice root growth (Chen et al.

2004). Prieto et al. (2011) reported that the exposure of rice plants to a mixture of Aphanizomenon ovalisporum and Microcystis aeruginosa cell extracts containing the cyanotoxins cylindrospermopsin and MC-LR resulted in a significant increase in glutathione S-transferase and glutathione peroxidase activities, suggesting a synergistic effect of both extracts.

The objective of the present work was to examine the effects of $M$. aeruginosa extracts with MC-LR concentrations between 0 and $781 \mathrm{~g} / \mathrm{L}$, which cover the concentrations more commonly found in the environment (van Apeldoorn et al. 2007; Campos et al. 2013). This approach will contribute to an enhancement of our understanding of the impact of cyanobacterial toxins on this important crop. Since most studies focus on the toxicological effects produced by high concentrations of MC-LR, this work attempted to determine whether low, environmentally relevant toxin concentrations are deleterious to rice plants or not. Plants were exposed to M. aeruginosa extracts during 2 or 7 days, to mimic short and semi-chronic exposure. 12 and 20 day-old plants were considered to study the effects of MC-LR in early stage of development of this crop. Rice plants were analysed regarding biomass, chlorophyll fluorescence, GST and GPx activity, and protein expression analysis by twodimensional gel electrophoresis (2DE) and protein identification by matrix-assisted laser desorption/ionization time of flight/time of flight (MALDITOF/TOF) mass spectrometry. Biochemical data was gathered in order to register effects that may not be observed by standard physiological parameters. Significant changes in rice proteome are reported, highlighting the cellular stress induced by toxic M. aeruginosa extracts in rice seedlings.

Materials and methods

Cyanobacteria culture and toxic extract preparation

Microcystis aeruginosa (LEGE 91094) cultures were established as described by Saker et al. (2005) under sterile conditions in $6 \mathrm{~L}$ glass containers with $4 \mathrm{~L}$ of Z8 medium (Kó tai 1972), at $25^{\circ} \mathrm{C}$, under $22 \mathrm{1Em}^{-2} \mathrm{~s}^{-1}$ light intensity, and a light/dark period of $14 / 10 \mathrm{~h}$.

After 4 weeks of growth, biomass was collected by centrifugation at $4{ }^{\circ} \mathrm{C}$, during $15 \mathrm{~min}$, at 4,4959g and thereafter lyophilized (Pinheiro et al. 2013). Freeze-dried M. aeruginosa cells were extracted in aqueous methanol 50 $\%(\mathrm{v} / \mathrm{v})$ through continuous stirring for $20 \mathrm{~min}$ at room temperature. The sample was then sonicated in a water bath for $15 \mathrm{~min}$ at room temperature and subsequently ultrasonicated in an ice bath at $60 \mathrm{~Hz}$ (VibraCell 50-sonics \& Material Inc. Danbury, CT, USA) with five cycles of $1 \mathrm{~min}$. The resulting slurry was centrifuged at $10,0009 \mathrm{~g}$ for $15 \mathrm{~min}$ to remove cell debris. The supernatant was then dried by 
rotary evaporation at

$35{ }^{\circ} \mathrm{C}$. The resulting residue was then resuspended in $40 \mathrm{~mL}$ of distilled water and the extract was stored at $-20{ }^{\circ} \mathrm{C}$ prior to use. MC-LR concentration was determined by HPLCDAD as described in section "Detection and quantification of microcystin-LR".

Detection and quantification of microcystin-LR

MC-LR from M. aeruginosa toxic extracts was quantified by high performance liquid chromatography (HPLC-DAD) based on the procedure described by Ramanan et al. (2000). The linear gradient elution consisted of (A) $\mathrm{MeOH}$ ? $0.1 \%$ trifluoroacetic acid and (B) $\mathrm{H}_{2} \mathrm{O} ? 0.1 \% \mathrm{TFA}(55 \% \mathrm{~A}$ and $45 \%$ at $0 \mathrm{~min}, 65 \% \mathrm{~A}$ and $35 \% \mathrm{~B}$ at $5 \mathrm{~min}, 80 \% \mathrm{~A}$ and $20 \% \mathrm{~B}$ at $10 \mathrm{~min}, 100 \% \mathrm{~A}$ at $15 \mathrm{~min}, 55 \% \mathrm{~A}$ and $45 \% \mathrm{~B}$ at 15.1 and $20 \mathrm{~min}$ ) with a flow rate of $0.9 \mathrm{~mL} / \mathrm{min}$. The injected volume was $40 \mathrm{1L}$. The DAD range was $210-400 \mathrm{~nm}$, with a fixed wavelength at $238 \mathrm{~nm}$. The MCLR was then separated on a Merck Lichrospher RP-18 endcapped column (250 mm $94.6 \mathrm{~mm}$ i.d., $5 \mathrm{~lm}$ ) equipped with a guard column (494 mm, 5 1m) both maintained at $45{ }^{\circ} \mathrm{C}$. Calculations were made using the external standard $\operatorname{method}\left(\mathrm{y}=53456 \cdot \mathrm{x}-22,587 ; \mathrm{R}^{2}=0.99701\right)$.

The cyclic peptide was also analysed by the analytical method of MALDI-TOF/TOF using the procedure described for protein identification ("Protein identification" section). MC-LR was detected by searching the peak signal at $995.0 \mathrm{~m} / \mathrm{z}$.

\section{Rice cultures}

Peeled Albatros variety rice seeds were sterilized and washed with hydrogen peroxide $10 \%(\mathrm{v} / \mathrm{v})$ during $10 \mathrm{~min}$ to prevent fungal and bacterial growth. Seeds were then washed three times with sterile distilled water during $10 \mathrm{~min}$, treated with ethanol $70 \%(\mathrm{v} / \mathrm{v})$ for $5 \mathrm{~min}$, rinsed with distilled water, and subsequently hydrated for $1 \mathrm{~h}$ in sterile distilled water under agitation (Miché and Balandreau 2001).

Seeds were germinated for 12 days in glass trays with wet filter paper and sealed with plastic wrap, at $25^{\circ} \mathrm{C}$ and under $22 \mathrm{1Em}^{-2} \mathrm{~s}^{-1}$ light intensity with a light/dark period of 14/10 h. Water was used on the first 3 days of incubation and then changed to Yoshida medium (Yoshida et al.

1976). The medium was replaced every 3 days from then on. Rice seedlings with 12-days and 2-3 young leaves were subsequently grown in hydroponic cultures at $23{ }^{\circ} \mathrm{C}$ and $133 \mathrm{1Em}^{-2} \mathrm{~s}^{-1}$ light intensity with a light/dark period of $14 / 10$ h. Rice was grown in $750 \mathrm{~mL}$ Yoshida medium renewed every 2-3 days. Plant growth and oxidative stress studies were thereafter undertaken with 12- and 20-day-old rice plants.

Plant exposure to toxic M. Aeruginosa extract
The following plant exposure experiments to toxic $M$. aeruginosa extracts were undertaken:

1. 20-day-old rice plants were exposed to $0.26 ; 13$ and $78 \mathrm{1g} / \mathrm{L}$ MC-LR crude extracts, applied to the nutrient solution, for 2 days.

2. 20-day-old rice plants were exposed to $0.26 ; 13$ and $78 \mathrm{1g} / \mathrm{L}$ MC-LR crude extracts for 7 days. The nutrient solution and the toxic extracts were replaced twice.

3. 12-day-old rice seedlings were exposed to 13 and $78 \mathrm{1g} / \mathrm{L}$ MC-LR crude extracts, applied to the nutrient solution, for 2 days.

Experiments were performed in triplicate $(\mathrm{n}=3)$ and control groups were maintained with nutrient solution without toxic extracts (0 1g/L MC-LR). At the end of the experiments, PSII fluorescence was measured and 3 groups of roots and leaves from each experimental replicate collected separately, weighted, frozen in liquid nitrogen, and kept at $-80{ }^{\circ} \mathrm{C}$ until being processed for enzymatic assays or for proteomic analysis (performed only on the experiment with 12-day-old plants). Although high concentrations of MCs have been reported in cyanobacterial blooms, the range of concentrations selected for this study are more frequently observed in water bodies, facilitating the comparison of the laboratorial studies with real case scenarios (Oh et al. 2001; Rivasseau et al. 1999; Sivonen et al. 1999). Acute ( 2 days) and sub-chronic ( 7 days) periods of expo- sure could provide further insight into the tolerance of plants to toxic cyanobacterial compounds and the physiological and biochemical responses.

\section{Chlorophyll fluorescence}

$\left(10,0009 \mathrm{~g}, 4{ }^{\circ} \mathrm{C}, 20 \mathrm{~min}\right)$ and the supernatant kept at $-80{ }^{\circ} \mathrm{C}$. Protein concentration was determined by the Bradford method (Bradford 1976).

GPx activity was determined through the methods described by Flohé and Gunzler (1984) and Lawrence and Burk (1976) by measuring the consumption of NADPH. The samples were diluted to $0.4 \mathrm{mg} / \mathrm{mL}$ of protein and $1001 \mathrm{~L}$ of diluted sample were added to each well of a 96 well microplate. The reaction solution with GSH $(1 \mathrm{mM})$, NADPH $(0.1 \mathrm{mM})$, GR $(0.08 \%, \mathrm{v} / \mathrm{v})$ in phosphate buffer $(0.08 \mathrm{M}) \mathrm{pH} 7.5$ was prepared and $80 \mathrm{1L}$ added to each well. To initiate the reaction, $20 \mathrm{1L}$ of $0.0075 \%(\mathrm{v} / \mathrm{v}) \mathrm{H}_{2} \mathrm{O}_{2}$ were added to the samples. The activity was monitored by registering the absorbance at $340 \mathrm{~nm}$ every $20 \mathrm{~s}$ during $5 \mathrm{~min}$ in a microplate reader (BioTek, Synergy ST, Winooski VT, USA).

GST activity was determined through the method described by Habig et al. (1974), by measuring the formation of the complex between glutathione and the enzyme substrate 1-chloro-2,4-dinitrobenzene (CDNB). For this assay, the samples were diluted to $0.3 \mathrm{mg} / \mathrm{mL}$ of protein, and $100 \mathrm{LL}$ of diluted sample were added to each well. The reaction 
solution with CDNB (10 mM), GSH (60 mM) in phosphate buffer $(0.3 \mathrm{M}) \mathrm{pH} 6.5$ was prepared and 200 1L were added was monitored as described for GPx assay.

GPx and GST activities were determined using the following expression

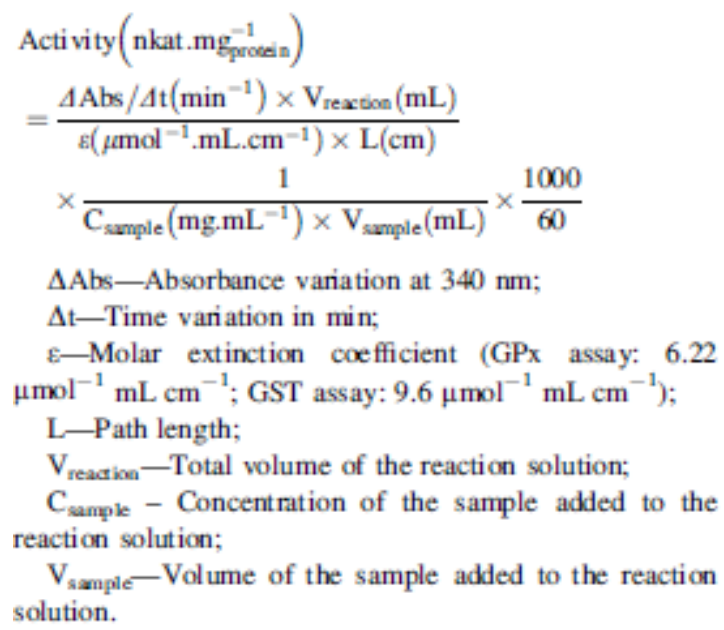

Chlorophyll fluorescence in 20-day old plants was determined through pulse amplitude modulation (PAM) fluorometry with PAM 2000 (Walz, Effeltrich, Germany).

Plants were dark adapted for at least $30 \mathrm{~min}$, and leavessubsequently illuminated with a pulse of saturating light. The fluorescence emitted was immediately recorded by the instrument. This procedure allows measuring the maximum fluorescence yield of photosystem II (Fv/Fm) that is directly related with the functional state of the PSII protein complex and the photosynthetic efficiency of the plants (Maxwell and Johnson 2000). This procedure was repeated for each replicate of each treatment, and for the control.

\section{GPx and GST activity determination}

To assess oxidative stress in plants, activities of glutathione S-transferase (GST) and glutathione peroxidase (GPx) were determined. For protein extraction, plant tissues were disrupted in a mortar with the aid of liquid nitrogen, and homogenized with $1 \mathrm{~mL}$ of phosphate buffer $0.08 \mathrm{~mol} \mathrm{~L}^{-1}$ (pH 7.5) per $0.2 \mathrm{~g}$ of tissue. The mixture was centrifugedDAbs - Absorbance variation at $340 \mathrm{~nm}$;

Dt-Time variation in min;

e-Molar extinction coefficient (GPx assay: 6.22 1 $\mathrm{mol}^{-1} \mathrm{~mL} \mathrm{~cm}^{-1}$; GST assay: $9.6 \mathbf{1 m o l}^{-1} \mathrm{~mL} \mathrm{~cm}^{-1}$ );

L-Path length;

$\mathrm{V}_{\text {reaction }}$-Total volume of the reaction solution;

$\mathrm{C}_{\text {sample }}$ - Concentration of the sample added to the reaction solution;

$\mathrm{V}_{\text {sample }}$-Volume of the sample added to the reaction solution. to each well to start the reaction. GST activity

Protein extraction from rice tissues for two-dimensional gel electrophoresis

Plant tissues were macerated in liquid nitrogen and proteins precipitated using $2 \mathrm{~mL}$ of cold acetone precipitation solution with TCA $(10 \%, \mathrm{v} / \mathrm{v})$ and b-mercaptoethanol $(0.07 \%, \mathrm{v} / \mathrm{v})$ per $0.1 \mathrm{~g}$ of tissue (Campos et al. 2012). The mixture was kept at $-20{ }^{\circ} \mathrm{C}$ for $1 \mathrm{~h}$ and then centrifuged at $4,4959 \mathrm{~g}$ for $25 \mathrm{~min}$ at $0{ }^{\circ} \mathrm{C}$. The protein pellet was resuspended in equal volume of acetone washing solution with b-mercaptoethanol $(0.07 \%, \mathrm{v} / \mathrm{v})$. The mixture was stored during $1 \mathrm{~h}$ at $-20{ }^{\circ} \mathrm{C}$ and centrifuged in the same conditions. The supernatant was discarded and the protein pellet dried in a rotating evaporator (Acid Resistant Centrivap Concentrator and Centrivap Cold Trap, LABCONCO, Kansas City, MO, USA) for $30 \mathrm{~min}$. The protein pellet was solubilized in $2 \mathrm{~mL}$ of resolubilisation buffer with urea (7 M), thiourea (2 M), CHAPS (4 \%, w/v), DTT (65 mM), ampholytes $\mathrm{pH} 3-10(0.8 \%$, v/v) per $0.1 \mathrm{~g}$ of pellet (Campos et al. 2012). Protein solubilisation was undertaken for $1 \mathrm{~h}$ and then centrifuged at 10,0009g during $30 \mathrm{~min}$ and $4{ }^{\circ} \mathrm{C}$. Protein supernatants were stored at $-80{ }^{\circ} \mathrm{C}$. Total protein content was determined through a Bradford assay.

First dimension gel electrophoresis: isoelectric focusing (IEF)

Protein samples $(150 \mathrm{lg})$ were diluted to $125 \mathrm{IL}$ resolubilisation buffer. Samples were centrifuged at $10,0009 \mathrm{~g}$ during $10 \mathrm{~min}$ and loaded in $7 \mathrm{~cm}$ and 4-7 $\mathrm{pH}$ range IEF gel strips (Bio-Rad, Hercules, CA,USA). Proteins were there- after separated according to their isoelectric point (pI) in a Protean IEF cell (Bio-Rad) with the following program: $16 \mathrm{~h}$ at $50 \mathrm{~V}$ (active strip rehydration); step 1, 15 min at $250 \mathrm{~V}$; step 2, $2 \mathrm{~h}$ voltage gradient to 4,000 V (linear ramp); step 3,

4,000 V until achieving 10,000 V/h (linear ramp). After the first dimension, IEF gel strips were stored at $-20{ }^{\circ} \mathrm{C}$ until performing the second dimension, sodium dodecyl sulfate polyacrylamide gel electrophoresis (SDS-PAGE) (Campos et al. 2012).

\section{Second dimension gel electrophoresis: SDS-PAGE}

After IEF, the gel strips were equilibrated using $10 \mathrm{mg}$ / $\mathrm{mL}$ dithiothreitol followed by $25 \mathrm{mg} / \mathrm{mL}$ iodoacetamide in urea $(6 \mathrm{M})$, glycerol $(30 \%, \mathrm{v} / \mathrm{v})$, SDS $(2 \%, \mathrm{w} / \mathrm{v})$ as described in Campos et al. (2009). This procedure reduces and alkylates the proteins. The IEF gel strips were quickly inserted on top of $12 \%$ (w/v) acrylamide SDS-PAGE slab gels (size $8.3 \mathrm{~cm} 97 \mathrm{~cm}$ ). A solution of melted agarose $0.5 \%(\mathrm{w} / \mathrm{v})$ was used to seal the gel 
strip in the second dimension gel. Proteins were thereafter separated in a miniProtean II cell (Bio-Rad) at $150 \mathrm{~V}$. After electrophoresis, gels were stained with Colloidal Coomassie Blue (Heinemeyer et al. 2007; Neuhoff et al. 1988).

Gel analysis

2DE Gel images were acquired with a GS-800 Calibrated Densitometer (Bio-Rad, Hercules, CA, USA) and protein spots were detected automatically with PDQuest 2-D Analysis Software (Bio-Rad, Hercules, CA, USA). Sensitivity parameters were reproduced for each gel image, and spot detection and matching were done manually. Protein spot intensities were normalized in terms of the total den- sity in the gel image. For protein expression analysis, a master gel was obtained in the software, detecting all the spots present in the $2 \mathrm{DE}$ gel images. The presence or absence of spots and quantitative variations in spot intensities were analysed, comparing each spot's intensity in each of all three experimental groups with each other. Only spots that were detected in at least two replicate gels were taken into consideration. Quantitative variations in spot intensity were statistically validated using $\mathrm{t}$ Student test ( $\mathrm{P} B$ 0.05). Three gels were done regarding each experimental condition $(\mathrm{n}=3)$.

Protein identification
Differentially expressed proteins were excised from the 2DE gels and in gel trypsin digested following the procedure described in Campos et al. (2012). The tryptic pep- tides were desalted and concentrated using reversed phase microcolumns (Gobom et al. 1999). The peptides were eluted directly onto the MALDI plate using the matrix a- cyano-4hydroxycinnamic acid $(5 \mathrm{mg} / \mathrm{mL})$ prepared in acetonitrile $(70 \%, \mathrm{v} / \mathrm{v})$ and TFA $(0.1 \%$, v/v). Samples were analyzed by MALDI-TOF/TOF Mass spectrometry (4700 Proteomics Analyzer, AB SCIEX, Foster City, CA, USA). Peptide mass spectra data was collected in positive MS reflector mode in the range of 700-4,000 (m/z) and was calibrated internally using trypsin autolysis peptide peaks. Several of the highest intensity and/or relevant non-tryptic peaks were selected for MS/MS analysis. Proteins were identified by combination of the Peptide Mass Fingerprint and MS/MS peptide sequencing approaches following an already published procedure (Gomes et al. 2013) using the software GPS Explorer (Version 3.6; AB SCIEX). Proteins were searched in a locally stored copy of the two sections of the UniProtKB protein sequence knowledgebase (Swiss- Prot and TrEMBL, release 2011_12) using the Mascot search engine (Version 2.1.04) (Perkins et al. 1999). The search included peaks with a signal-to-noise ratio greater than 10 and allowed for up to two missed trypsin cleavage sites. For a match to be considered, a confidence interval (CI) of at least of $99 \%$, calculated by AB SCIEX GPS Explorer software, was required. 

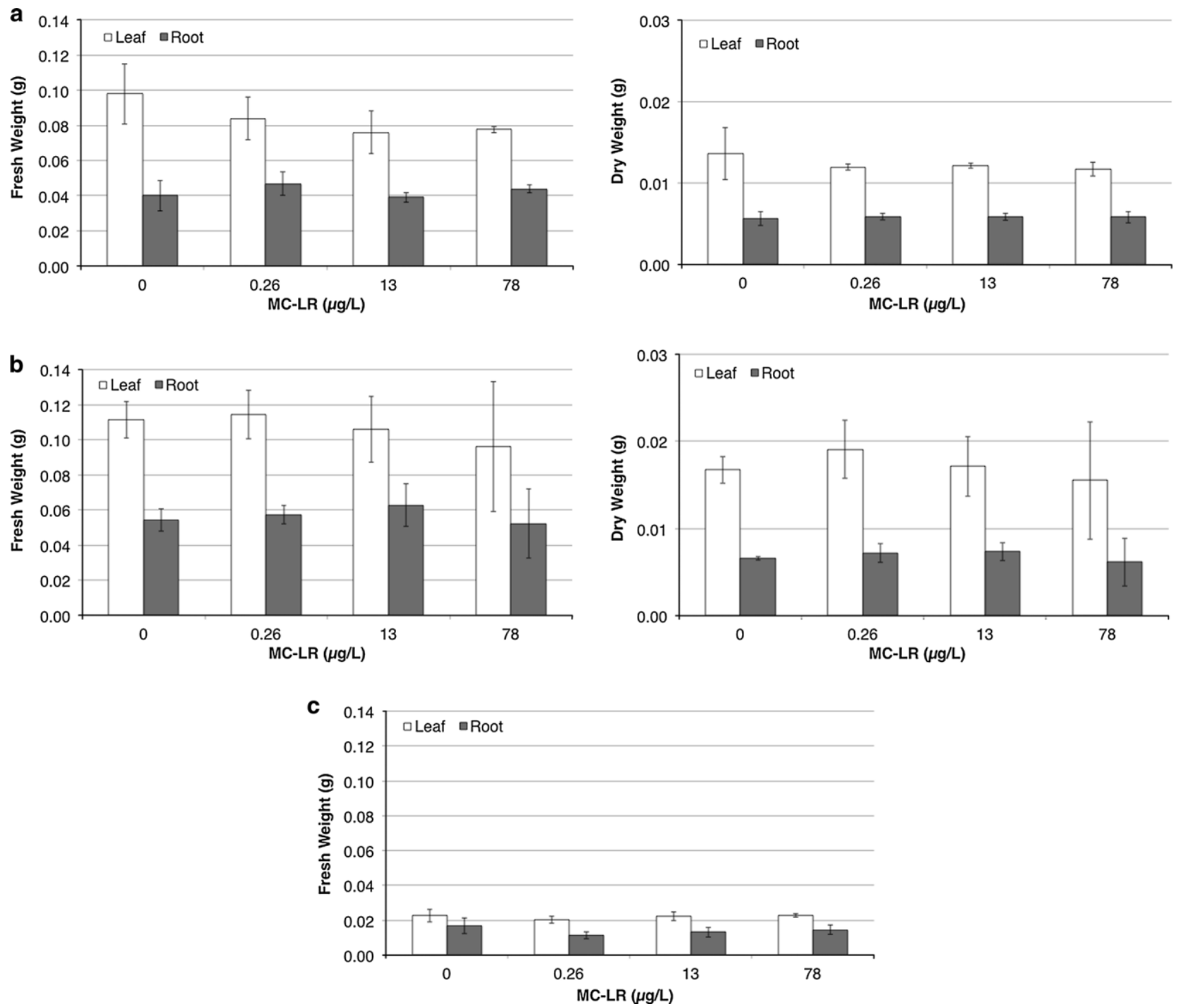

Fig. 1 Fresh weight and dry weight values from 20 days-old rice plants exposed for 2 days (a), and 7 days (b), and 12 days-old plants exposed for 2 days (c) to M. aeruginosa extract with MC-LR at 0.26, 13 and $78 \mathrm{1g} / \mathrm{L}$. Results expressed as mean value \pm standard deviation

\section{Statistical analysis}

For statistical analysis of the results obtained $(n=3)$ Student's t test was used, with a confidence limit of $95 \%$ $(\mathrm{P} \backslash 0.05)$.

\section{Results}

Rice growth parameters

No significant differences in root and leaf fresh and dry weights from 20-day-old rice plants exposed for 2 days to M. aeruginosa extracts were registered, as displayed in Fig. 1a. Increasing the time of exposure to M. aeruginosa extracts to 7 days did not affect rice growth (Fig. 1b), neither did exposing rice seedlings (12-days-old) to $\mathrm{M}$. aeruginosa extracts with the same MC-LR concentrations for 2 days (Fig. 1c).

\section{Rice photosynthetic efficiency}

Maximum quantum yield of PSII is a reliable measurement of photosynthetic efficiency. It was registered here to complement the characterization of the physiological status of rice plants. No variations were reported in the maximum quantum yield of plants exposed to M. aeruginosa extracts during 2 days (Fig. 2a), suggesting that the presence of MC-LR in the nutrient solution, in an interval of concentrations between 0.26 and $78 \mathrm{1g} / \mathrm{L}$, may not affect 

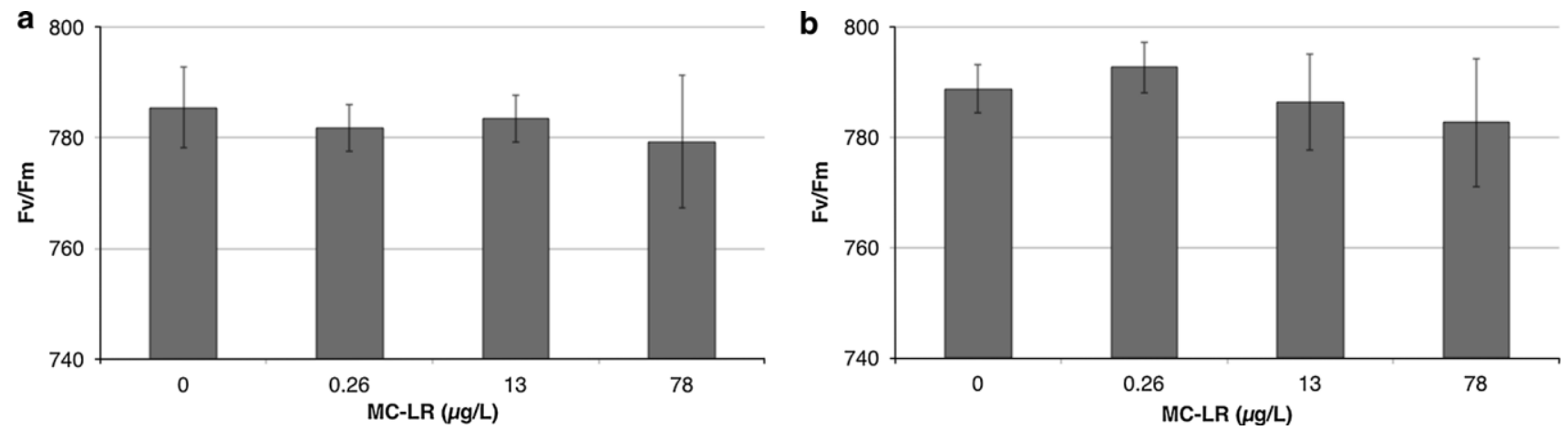

Fig. 2 Maximum fluorescence values (Fv/Fm) from 20 day-old rice plants exposed for 2 days (a), and 7 days (b) to M. aeruginosa extract, with MC-LR at 0.26, 13 and $78 \mathrm{1g} / \mathrm{L}$. Results expressed as mean value \pm standard deviation
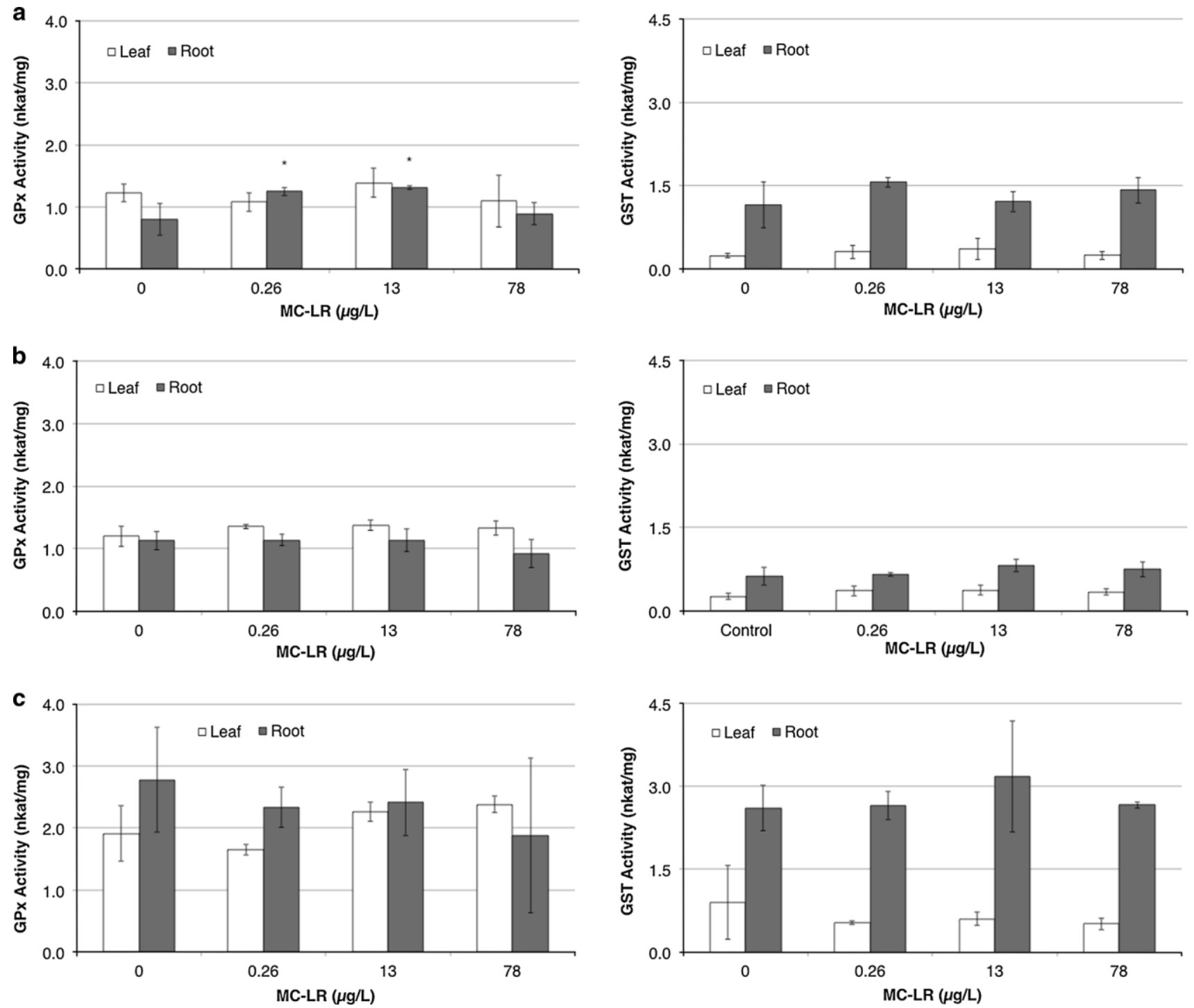

Fig. 3 GPx and GST activities from 20-day-old rice plants exposed for 2 days (a), and 7 days (b), and 12-day-old rice plants exposed for 2 days to M. aeruginosa extract, with MC-LR at $0.26,13$ and $78 \mathrm{1g} / \mathrm{L}$

(c). Results are expressed as mean value \pm standard deviation. Data significantly different from control on GPx activity assay (a) on roots (*) (Student's test, $\mathrm{P} \backslash 0.05)$ 
photosynthesis. Moreover, increasing the time of plant exposure to M. aeruginosa extracts to 7 days did not alter the maximum quantum yield in rice plants (Fig. 2b).

\section{GPx and GST enzyme activity}

No significant differences in root and leaf GST activities were registered in 20-day-old rice plants exposed for 2 or 7 days to M. aeruginosa extracts (Fig 3a, b). However, it was possible to detect an increase in root-GPx activity during the acute exposure ( 2 days) to 0.26 and $13 \mathrm{lg} / \mathrm{L}$ MC-LR M. aeruginosa extracts (Fig. 3a). Regarding the other experimental conditions tested, GPx activity remained close to control levels (Figs. 3b, c). These results suggests that exposure to MC-LR in this range of concentrations have minimal impact on these enzymes' activity.

Rice proteomic analysis

2DE and MALDI-TOF/TOF mass spectrometry approaches were applied to study rice root and leaf proteomes. In order to increase the number of proteins covered by the study, a large fraction of the proteome was first separated over a broad $\mathrm{pI}$ interval (pI 4-7), and subsequently according to the molecular mass (MM) (from *20 to $100 \mathrm{kDa}$ ). Only 12 day-old plants were considered for proteomics analysis since the results accomplished on GPx and GST activity and biomass (fresh weight data) suggest that there are no major differences in the response of plants in the two growth stages to $M$. aeruginosa extracts and MC-LR. Moreover, we expect this analysis to be sufficient to infer on whether MC-LR affects rice proteome or not. High resolution of protein spots was achieved in 2DE gels over the range of $\mathrm{pI}$ and $\mathrm{MM}$ intervals chosen (Fig. 4). Differential protein expression was analysed taking into consideration the quantitative variations in protein abundance. A summary of the proteome variations detected by this method is displayed in Fig. 5.51 and 42 proteins were differentially expressed in roots and leaves, respectively, from exposed rice groups, in comparison to control. Moreover, variations between exposed groups comprised 116 root and 6 leaf proteins. Only 2 and 4 detected proteins from roots and leaves respectively, overlapped at the variations detected in 13 and

$78 \mathrm{1g} / \mathrm{L}$ MC-LR exposed groups. The high number of differentially expressed proteins (DEP) associated to the rice root system might be related to the multiple metabolic processes putatively involved in the organ response to MCLR and other M. aeruginosa bioactive compounds.

Protein identification and assignment of functional groups

In Table 1, the functions and expression levels of each identified protein are shown. 28 proteins were identified combining MS and MS/MS analysis; 9 in roots and 19 in leaves. The most representative protein groups in roots are involved in protein folding and stress response, and cell signalling and gene expression regulation, while in leaves protein folding and stress response, and energy and carbohydrate metabolism are the most representative protein functional groups (Table 1).

Functional groups specifically assigned to roots are cell signalling and gene expression regulation (14-3-3 protein and G-box binding factor) and cell structure (tubulin alpha1). Instead, methylmalonate semi-aldehyde dehydrogenase, involved in inositol and propanoate metabolism, glutamine synthetase, a key enzyme from the nitrogen metabolism, and flavone $3^{0}$-O-methyltransferase, acting in flavonoid biosynthesis, were identified specifically in leaves. All these proteins were down-regulated in $13 \mathrm{lg} / \mathrm{L}$ MC-LR treated plants with the exception of glutamine synthetase, which was down-regulated in $78 \mathrm{1g} / \mathrm{L}$ MC-LR treated plants.

In roots from $13 \mathrm{1g} / \mathrm{L}$ MC-LR treated plants, all proteins were down-regulated in respect to control plants. Nevertheless, in roots from $78 \mathrm{1g} / \mathrm{L}$ MC-LR treated plants, all proteins were up-regulated in regard to $131 \mathrm{~g} / \mathrm{L}$ MCLR and control plants. In leaves, the majority of proteins were down-regulated.

Six and three folding and stress response proteins were down-regulated in leaves from plants exposed to 13 and $78 \mathrm{1g} / \mathrm{L}$ MC-LR, respectively, in comparison with the control group. One cell death associated protein is upregulated in leaves when comparing $78 \mathrm{1g} / \mathrm{L}$ MC-LR treated plants to the $13 \mathrm{1g} / \mathrm{L}$ MC-LR plants. In roots, chaperonin was down-regulated in $13 \mathrm{lg} / \mathrm{L}$ MC-LR treated plants in regard to control plants, and heat shock protein 83 was up-regulated when comparing the $78 \mathrm{1g} / \mathrm{L}$ MC-LR treatment with the control group.

Alpha tubulin, a cytoskeleton component, was downregulated in roots of $13 \mathrm{1g} / \mathrm{L}$ MC-LR treated plants, contrasting the expression in $78 \mathrm{1g} / \mathrm{L}$ MC-LR treated plants.

14-3-3 protein, g-box binding factor, cell signalling and gene expression regulation proteins, were down-regulated in roots from $13 \mathrm{1g} / \mathrm{L}$ MC-LR plants in comparison to control and $781 \mathrm{~g} / \mathrm{L}$ MC-LR plants.

Pyruvate decarboxylase isozyme 2, sucrose synthase 1, sucrose synthase, fructokinase-2 and triosephosphate isomerase, are proteins acting in energy and carbohydrate metabolism. In leaves, sucrose synthetase 1 was downregulated in both MC-LR groups, while the second isoform was up-regulated in the $13 \mathrm{lg} / \mathrm{L}$ MC-LR group only. Fructokinase and triosephosphate isomerase were downregulated in 13 and $78 \mathrm{1g} / \mathrm{L}$ MC-LR groups, respectively. Root pyruvate decarboxylase was up-regulated in $78 \mathrm{1g} / \mathrm{L}$ MC-LR treated plants in regard to control and to $13 \mathrm{1g} / \mathrm{L}$ MC-LR plants. 


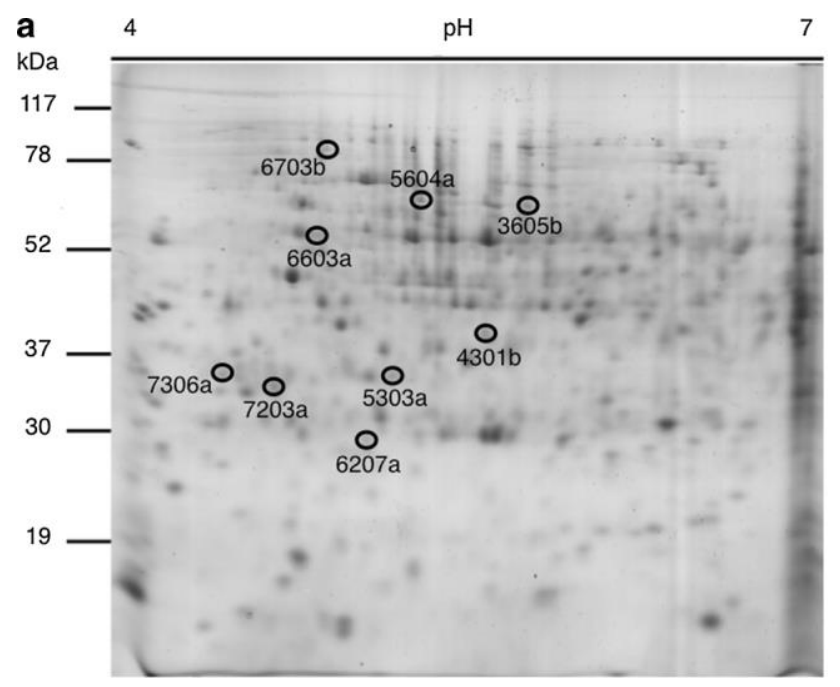

Fig. 4 Two-dimensional maps of rice root (a) and leaf (b) proteins from 12-day-old control plants. Total protein loaded was $150 \mathrm{Ig}$ and gels were stained with Colloidal Coomassie Blue. Proteins
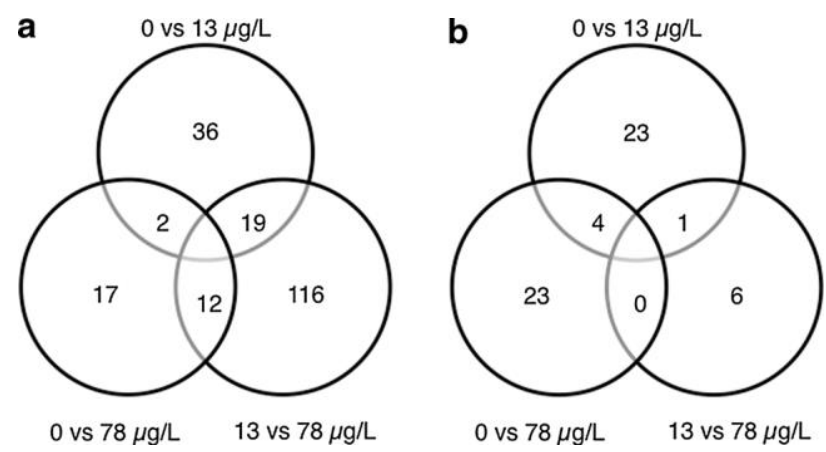

Fig. 5 Venn diagram representation of the number of differentially expressed proteins (DEP) detected after comparison of root (a) and leaf (b) proteomes from 12-day-old rice plants exposed for 2 days to $0.0,13$ and 78 1g/L MC-LR

$60 \mathrm{~S}$ acidic ribosomal protein, asparagine-tRNA ligase and protein disulfide-isomerase are involved in protein biosynthesis and folding. Asparagine-tRNA ligase and protein disulfide-isomerase were down-regulated in leaves from $13 \mathrm{1g} / \mathrm{L}$ MC-LR group in regard to the control. In roots, $60 \mathrm{~S}$ acidic ribosomal protein was up-regulated in treatment $78 \mathrm{1g} / \mathrm{L} \mathrm{MC}-\mathrm{LR}$ in relation to control and to $13 \mathrm{lg} / \mathrm{L}$ MC-LR treated plants.

One uncharacterized protein was up-regulated in roots from $78 \mathrm{1g} / \mathrm{L}$ MC-LR group in regard to control and to $13 \mathrm{1g} / \mathrm{L}$ MC-LR groups. Other two uncharacterized proteins were up-regulated in leaves from $13 \mathrm{lg} / \mathrm{L} \mathrm{MC}$ LR group in regard to control.

Chloroplast PsbO2 and ATP-dependent zinc metalloprotease FTSH 2 chloroplastic proteins intervene in photosynthesis. Both proteins were down-regulated in roots and leaves from $13 \mathrm{lg} / \mathrm{L}$ MC-LR treated plants in regard to control plants.

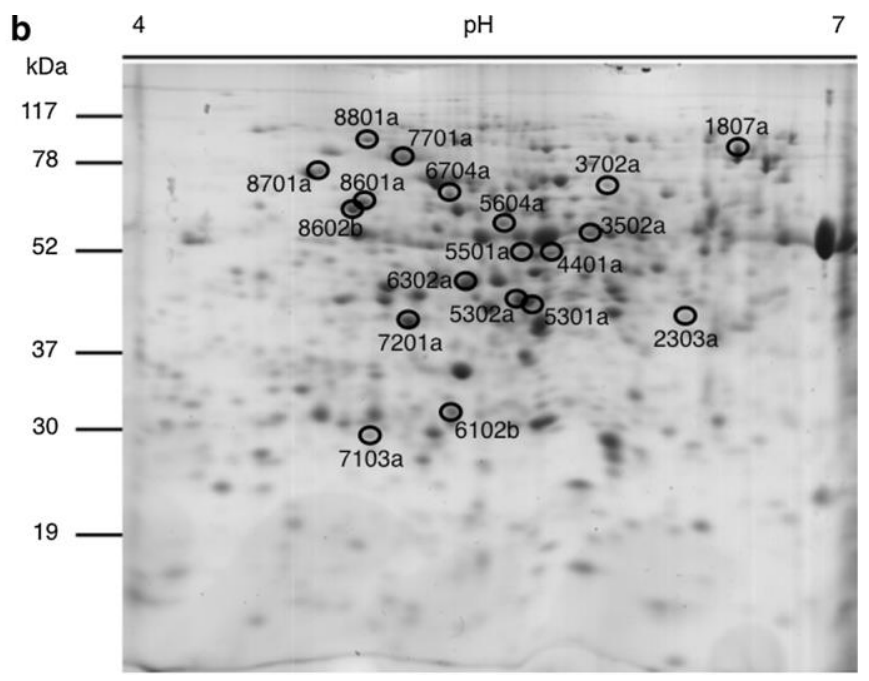

differentially expressed in 12-day-old plants exposed during 2 days to $0.0,13$ and $78 \mathrm{Ig} / \mathrm{L} \mathrm{MC-LR}$ (Table 1) are marked in the maps with a circle

\section{Discussion}

Physiological effects of toxic M. aeruginosa extract in rice plants

In none of the assays a significant difference in plant weight or photosynthetic efficiency between any of the treatments in comparison to their respective control groups was detected. It appears that exposure to a $\mathrm{M}$. aeruginosa toxic extract in concentrations corresponding to MC-LR in a range of $0.26-781 \mathrm{~g} / \mathrm{L}$, for 2 or 7 days, doesn't impair plant growth or inhibits photosynthetic efficiency.

A study was made in which rice and rapeseed plants were exposed to an extract in doses equivalent to $0,24,000$, $120,000,600,000$ and 3,000,000 $1 \mathrm{~g} / \mathrm{L}$ MC-LR. In this study, seedling growth was inhibited, as well as the elongation of primary roots (Chen et al. 2004). However, the concentrations used were much higher than the ones in the present study, and the exposure was done on younger plants, which may have caused an increase in toxicity. Another study reports that rice plants exposed for 10 days to MC-LR in a range of 10-200 $1 \mathrm{~g} / \mathrm{L}$ were not affected in regard to the number of crown roots and lateral roots (Chen et al. 2012). These results may be comparable to the absence of root growth inhibition obtained in the present work. In the same study, plant growth was significantly inhibited after 5 days of exposure to high concentrations, $500-4,000$ 1g/L MC-LR.

A study comparing the effects of exposure of rice and rapeseed plants to a mixture of $\mathrm{MC}$ variants found indications that rice plants may have evolved a mechanism that makes them more tolerant to MC toxicity (Chen et al. 2004). Although the growth of rice plants was impaired 
due to 
Table 1 Differential expression of identified proteins from root and leaf of 12-day-old rice plants exposed for $48 \mathrm{~h}$ to $\mathrm{M}$. aeruginosa extracts containing MC-LR at 13 and $78 \mathrm{1g} / \mathrm{L}$, in different functional groups

\begin{tabular}{|c|c|c|c|c|c|c|c|c|c|c|}
\hline \multirow[b]{3}{*}{$\begin{array}{l}\text { Oryza } \\
\text { sativa } \\
\text { L. }\end{array}$} & \multirow[b]{3}{*}{$\begin{array}{l}\text { Spot } \\
\#\end{array}$} & \multirow[b]{3}{*}{ Protein identification } & \multicolumn{6}{|l|}{ Spot intensity } & \multirow[b]{3}{*}{ Accesion Number } & \multirow[b]{3}{*}{ Biological function } \\
\hline & & & \multicolumn{6}{|c|}{ MC-LR (1g/L) } & & \\
\hline & & & 0.0 & 13 & & \multicolumn{3}{|l|}{78} & & \\
\hline \multirow[t]{9}{*}{ Root } & 6207 & Chaperonin & $287 \pm 78$ & $109 \pm 64$ & ; & $249 \pm 119$ & & & Q69Y99_ORYSJ & Protein folding, \\
\hline & 6703 & Heat shock protein 83 & $178 \pm 112$ & $217 \pm 51$ & & $1121 \pm 183$ & : & * & B6UCZ5_MAIZE & stress response \\
\hline & 7203 & 14-3-3 protein & $1107 \pm 316$ & $426 \pm 106$ & ; & $1213 \pm 210$ & & & Q10E23_ORYSJ & Cell signalling and \\
\hline & $1 / 306$ & G-box bindıng factor & $609 \pm 222$ & $200 \pm 58$ & ; & $612 \pm 60$ & & - & QUJCMU_URYSJ & $\begin{array}{l}\text { gun unpusosivn } \\
\text { regulation }\end{array}$ \\
\hline & 3605 & $\begin{array}{l}\text { Pyruvate decarboxylase } \\
\text { isozyme } 2\end{array}$ & $315 \pm 75$ & $208 \pm 37$ & & $523 \pm 56$ & : & * & B7ERZ5_ORYSJ & $\begin{array}{l}\text { Energy and } \\
\text { carbohydrate } \\
\text { metabolism }\end{array}$ \\
\hline & 4301 & $\begin{array}{l}60 \mathrm{~S} \text { acidic ribosomal } \\
\text { protein }\end{array}$ & $886 \pm 333$ & $633 \pm 260$ & & $1808 \pm 217$ & : & * & J3MQ37_ORYBR & $\begin{array}{l}\text { Protein biosynthesis } \\
\text { and folding }\end{array}$ \\
\hline & 5604 & $\begin{array}{l}\text { Putative uncharacterized } \\
\text { protein }\end{array}$ & $558 \pm 271$ & $441 \pm 129$ & & $1101 \pm 170$ & : & * & B8BD19_ORYSI & $\begin{array}{l}\text { Uncharacterized } \\
\text { proteins }\end{array}$ \\
\hline & 5303 & Chloroplast PsbO2 & $512 \pm 145$ & $141 \pm 19$ & ; & $418 \pm 104$ & & * & I0B7J2_NICBE & Photosynthesis \\
\hline & 6603 & Tubulin alpha-1 chain & $776 \pm 142$ & $346 \pm 146$ & ; & $1884 \pm 846$ & & * & Q10DN1_ORYSJ & Structural \\
\hline \multirow[t]{19}{*}{ Leaf } & 5301 & $\begin{array}{l}\text { Cell death associated } \\
\text { protein }\end{array}$ & $6329 \pm 347$ & $4063 \pm 411$ & ; & $2665 \pm 1926$ & ; & & Q6J657_ORYSJ & $\begin{array}{l}\text { Protein folding, } \\
\text { stress response }\end{array}$ \\
\hline & 5501 & $\begin{array}{l}\text { Cell death associated } \\
\text { protein }\end{array}$ & $850 \pm 107$ & $463 \pm 17$ & ; & $751 \pm 121$ & & * & Q6J657 & \\
\hline & 5604 & TCP-1/cpn60 chaperonin & $1135 \pm 5$ & $727 \pm 50$ & ; & $884 \pm 187$ & & & B8ALS4 & \\
\hline & 7701 & Heat shock protein $81-2$ & $2286 \pm 126$ & $970 \pm 375$ & ; & $880 \pm 311$ & ; & & Q69QQ6 & \\
\hline & 8701 & $70 \mathrm{kDa}$ heat shock protein & $1092 \pm 102$ & $836 \pm 12$ & ; & $1070 \pm 251$ & & & I1 R581 & \\
\hline & 8801 & $90 \mathrm{kDa}$ heat shock protein & $1156 \pm 190$ & $583 \pm 223$ & ; & $845 \pm 259$ & & & Q5Z9N8 & \\
\hline & 8602 & $\begin{array}{l}60 \mathrm{kDa} \text { chaperonin alpha } \\
\text { subunit }\end{array}$ & $2964 \pm 246$ & $2528 \pm 948$ & & $2380 \pm 191$ & ; & & Q2QU06 & \\
\hline & 1807 & Sucrose synthase 1 & $3812 \pm 298$ & $1479 \pm 611$ & ; & $1392 \pm 84$ & ; & & SUS1_ORYSJ & \multirow{4}{*}{$\begin{array}{l}\text { Energy and } \\
\text { carbohydrate } \\
\text { metabolism }\end{array}$} \\
\hline & 2303 & Sucrose synthase & $919 \pm 125$ & $1278 \pm 144$ & : & $1168 \pm 112$ & & & A2XHR1_ORYSI & \\
\hline & 7201 & Fructokinase-2 & $5047 \pm 160$ & $4388 \pm 282$ & ; & $4367 \pm 766$ & & & A2YQL4 & \\
\hline & 6102 & Triosephosphate isomerase & $2269 \pm 188$ & $1864 \pm 350$ & & $1789 \pm 192$ & ; & & A2Z3G7_ORYSI & \\
\hline & 3702 & Asparagine-tRNA ligase & $624 \pm 74$ & $274 \pm 108$ & ; & $548 \pm 182$ & & & Q93WM3_ORYSJ & \multirow{2}{*}{$\begin{array}{l}\text { Protein biosynthesis } \\
\text { and folding }\end{array}$} \\
\hline & 8601 & Protein disulfide-isomerase & $2653 \pm 304$ & $2136 \pm 103$ & ; & $2386 \pm 819$ & & & F4MG95 & \\
\hline & 4401 & $\begin{array}{l}\text { Putative uncharacterized } \\
\text { protein }\end{array}$ & $908 \pm 254$ & $470 \pm 83$ & ; & $679 \pm 415$ & & & A5BI23_VITVI & \multirow[t]{2}{*}{$\begin{array}{l}\text { Uncharacterized } \\
\text { proteins }\end{array}$} \\
\hline & 7103 & $\begin{array}{l}\text { Putative uncharacterized } \\
\text { protein }\end{array}$ & $1060 \pm 294$ & $470 \pm 151$ & ; & $705 \pm 232$ & & & A2YMN1_ORYSI & \\
\hline & 3502 & $\begin{array}{l}\text { Methylmalonate semi- } \\
\text { aldehyde dehydrogenase }\end{array}$ & $1081 \pm 9$ & $583 \pm 160$ & ; & $813 \pm 230$ & & & Q6Z4E4_ORYSJ & $\begin{array}{l}\text { Inositol, propanoate } \\
\text { and nitrogen }\end{array}$ \\
\hline & 6302 & Glutamine synthetase & $4453 \pm 401$ & $3560 \pm 753$ & & $3056 \pm 345$ & ; & & Q0J9E0 & metabolism \\
\hline & 6704 & $\begin{array}{l}\text { ATP-dependent zinc } \\
\text { metalloprotease FTSH 2, } \\
\text { chloroplastic }\end{array}$ & $955 \pm 242$ & $505 \pm 131$ & ; & $748 \pm 241$ & & & Q655S1 & Photosynthesis \\
\hline & 5302 & $\begin{array}{l}\text { Flavone } 3^{0}-\mathrm{O}- \\
\text { methyltransferase } 1\end{array}$ & $2289 \pm 600$ & $952 \pm 427$ & ; & $2333 \pm 1991$ & & & Q6ZD89 & $\begin{array}{l}\text { Flavonoid } \\
\text { biosynthesis }\end{array}$ \\
\hline
\end{tabular}


:: up-regulation in respect to control; ;: down-regulation in respect to control; *: up-regulation in respect to $13 \mathrm{1g} / \mathrm{L}(\mathrm{P} \backslash 0.05)$ 
exposure to MC at $120-3,000 \mathrm{1g} / \mathrm{mL}$ and the plants had their primary root growth inhibited, this effect can be partially overcome by developing more powerful lateral roots enabling the plant to take up nutrients and maintain the metabolism and growth (Chen et al. 2004). Fv/Fm values measured in this study lay between 780 and 817 . This indicates the plants were not at their optimal state of growth (Baker and Rosenqvist 2004; Maxwell and Johnson 2000) and parameters such as temperature and light intensity need to be established for this rice variety. Despite this condition, rice plants showed a constant growth, and no significant differences in Fv/Fm were registered between control and exposure groups indicating that exposure to $\mathrm{M}$. aeruginosa cell extract containing MC-LR does not cause photosystem II damage, or inhibition of plant's photosynthetic capacity.

Although the results obtained point to the tolerance of rice to M. aeruginosa extracts and MC-LR, this hypothesis should be taken with caution when considering field growing rice. One must bear in mind that field plants may be challenged by a combination of stress factors (e.g. pathogen attack, water contaminants, temperature stress, nutritional shortage, drought, etc.) reducing their ability to respond and cope with cyanotoxin's toxic activity. On the other hand, the hypothesis that growth inhibition effects induced by low toxin doses may arise with long term or chronic exposures cannot be discarded, and therefore this condition needs to be evaluated. In this aspect, 7-day exposure of rice up to $78 \mathrm{1g} / \mathrm{L} \mathrm{MC-LR}$ could be insufficient to report toxicity based on plant biomass (FW and DW) and PS II fluorescence. Licopersicum esculentum growth inhibition (e.g. stem length and plant biomass, FW, variations) was reported by El Khalloufi et al. (2012) in 30-day exposure experiments to $2.22-22.241 \mathrm{~g} / \mathrm{mL}$ MC M. aeruginosa extracts. PS II fluorescence was less sensitive than plant biomass, varying only in plants exposed to the highest toxin dose (El Khalloufi et al. 2012). Lahrouni et al. (2012) reported differences in growth of rhizobia inoculated Medicago sativa (e.g. shoot and root DW variations) when exposed for 6 weeks to $100 \mathrm{1g} / \mathrm{L} \mathrm{MC} \mathrm{M}$. aeruginosa extracts. Concomitantly, Saqrane et al. (2009) registered variations in FW and DW for Triticum durum, Zea mays, Pisum sativum and Lens esculenta plants exposed for 30-days to $0.5,1.05,2.1$ and $4.2 \mathrm{mg}$ equivalent $\mathrm{MC}-\mathrm{LR} / \mathrm{mL}$. Moreover, in all plants tested, and at the various $\mathrm{MC}$ concentrations, treatment with cyanobacterial extract produced a decrease in the Fv/Fm in regard to control. Fv/Fm decline as well as growth, was dose and plant species-dependent (Saqrane et al. 2009).

Biochemical response of rice plants exposed to toxic $\mathrm{M}$. aeruginosa extract

The enzyme GPx scavenges peroxides, which can arise in an organism exposed to environmental stress due to the presence of ROS, using reducing agents, such as the tripeptide glutathione (Miao et al. 2006; Navrot et al. 2006). When a plant is under oxidative stress, phospholipid hydroperoxide glutathione peroxidase (PHGPx), an enzyme in the GPx family that has been reported to be present in plants, is up-regulated (Eshdat et al. 1997; Faltin et al. 2010). PHGPx is a member of the GPx family, and it constitutes a defence against lipid peroxidation, since it can reduce phospholipid hydroperoxides and complex hydroperoxy lipids from biomembrane lipid layers, as well as $\mathrm{H}_{2} \mathrm{O}_{2}$ and other organic hydroperoxides (Faltin et al. 2010; Navrot et al. 2006). A study in which tobacco BY-2 cells were exposed to $50,0001 \mathrm{~g} / \mathrm{L}$ of MC-RR showed the gradual increase of GPx activity in a time dependent manner (Yin et al. 2005). Again, the exposure concentration used is very high, unlike the range used in the present study. In this work the only instance in which exposure to MC-LR producing $M$. aeruginosa cell extracts seemed to have an effect in GPx activity was when 20-day-old rice plants were exposed for 2 days to $M$. aeruginosa extract with 0.26 and $13 \mathrm{lg} / \mathrm{L}$ MC-LR. No significant differences in regard to control groups were found in other treatment groups, which can be attributed to the putative activation of defense mechanisms (e.g. systemic acquired resistance, SAR) in 20 day-old-plants exposed for 7 days to MC-LR, or to an elevated activity of GPx in 12-day-old plants.

GST is used as an indicator of physiological stress in an organism because it plays an important role, for example, in the oxidative stress defence and in detoxification of a variety of xenobiotic compounds, by binding glutathione to substrates, making them more polar and less reactive (Lee et al. 2011; Marrs 1996). In plants, it's involved in the detoxification of herbicides and pesticides, organic pollutants and naturally occurring toxins (Lee et al. 2011). GST protects cells from a wide range of stresses, including oxidative stress (Lee et al. 2011; Marrs 1996; Pflugmacher

2004). In the specific case of an organism exposed to MCs, GST seems to be involved in the toxin detoxification (Bibo et al. 2008; Crush et al. 2008; Saqrane et al. 2007). A study in which Arabidopsis thaliana suspension cells were exposed to 1,000 and $5,000 \mathrm{1g} / \mathrm{L}$ MC-RR for 2 days showed no GST activity variation in regard to control (Yin et al. 2005). It's of notice that this range of concentrations is much higher than the range used in this work (0.26-78 1g/L MC-LR). However, results from a study in which several spinach variants were exposed to low concentrations of MCs $(0.5 \mathrm{1g} / \mathrm{L})$ from a crude cell extract, both microsomal GST and soluble GST activities were elevated in all variants except for one, the increase being by 6-146\% in comparison to the control groups (Pflugmacher et al. 2007). Values for GST activity in control groups were $0.20-0.30 \mathrm{nkat} / \mathrm{mg}$ protein in microsomes, and between 1.00 and $2.00 \mathrm{nkat} / \mathrm{mg}$ protein in the cytosol, and in treatments they lay in a range from 0.30 to $0.80 \mathrm{nkat} / \mathrm{mg}$ protein in microsomes, and from 1.00 to 3.5 
nkat $/ \mathrm{mg}$ protein in the cytosol (Pflugmacher et al. 2007). Taking this into account, it would be expected to observe an increase in GST activity in rice plants exposed to M. aeruginosa cell extracts. On the other hand, in the present study, exposure of rice plants to $0.26-78 \mathrm{1g} / \mathrm{L}$ of MC-LR to a M. aeruginosa extract did not seem to influence GST's activity. Values of GST activity in leaves, both in control and treatments, fall in a range of $0.2-3.2 \mathrm{nkat} / \mathrm{mg}$ protein, with no significant differences between control and exposure groups which points to this toxin not having a detrimental effect on rice plant's oxidative stress level, nor on its need for increasing its detoxification mechanisms.

Taking into account the results obtained in GPx and GST enzymatic assays, we may consider that the used concentrations of MC-LR in M. aeruginosa extract did not induce oxidative stress in rice plants. It's possible that GPx and GST might not be the best biomarkers of physiological stress in rice. GST may lack sensitivity towards MC (Bibo et al. 2008; Lee et al. 2011; Marrs 1996; Saqrane et al. 2007), while GPx activity is low and its function poorly characterized in plants (Faltin et al. 2010; Navrot et al. 2006). Measurement of catalase, superoxide dismutase, glutathione, or products of lipid peroxidation, or protein phosphatase bioassays could be used in further assays to study the extension of oxidative stress in rice plants caused by exposure to MC-LR (Asensi et al. 1999; Chen et al. 2004; Lambert et al. 1994; Oh et al.

2001; Vinagre et al. 2012). In this regard, mass-spectrometry based sensitive methods have been suggested for the identification and quantitation of oxidative stress parameters and oxidation products (Lee and Britz-McKibbin 2009; Levison et al. 2013). On the other hand, the lack of response of the two biochemical markers may have been due to a poor capacity of the plant to take up and accumulate the toxin. In such a hypothesis, the toxicity induced inside the cells would be supressed with the basal GPx and GST levels. The research has been also emphasizing the genetic factors that contribute to the differences in GST and GPx activities between species and varieties. Since the enzymatic activities showed no response to the treatments, a more sensitive proteomics approach was employed to investigate further effects on plant metabolism.

Results obtained from proteomic analysis show that there were proteins with altered expression in plants exposed to toxic M. aeruginosa extract containing MC-LR (13 and $78 \mathrm{1g} / \mathrm{L}$ ) in comparison to the control groups. Another important point of this study, revealed by proteomics, is that different concentrations of the toxin in the medium may trigger different biochemical responses in plants.

Chaperonins and heat shock proteins are known to act in protein folding and to respond to a variety of stresses, being, therefore, recognized as important biomarkers of cellular stress. Several members of this class and two cell death associated proteins were down-regulated in roots and leaves of MC-LR treated plants, which may indicate that processes related with protein stability and function are affected and may impair plants' homeostasis (Wang et al. 2004). HSP83, which was an exception, was markedly over-expressed in roots of plants exposed to the highest toxin concentration. The down-regulation of a tubulin isoform in the lower MC-LR exposure concentration might indicate that structural alterations occur in root tissues under this exposure condition. The results also show that different MC-LR concentrations might induce different biochemical responses and particularly in the roots with HSP83 and proteins with functions in cell signalling and gene expression regulation, carbohydrate metabolism and protein biosynthesis displaying significant variations between treatments.

In rice leaves, processes related with protein folding and stress response, energy and carbohydrate metabolism are likely to be affected to a different extent in MC-LR treated plants, as assessed by the down-regulation of several protein markers. Variations in FTSH 2 and PsbO2 proteins would presuppose an alteration in the photosynthesis reactions and thereby in the levels of chlorophyll fluorescence. Nevertheless, this parameter was not altered in treated plants, which may evidence the low impact of $\mathrm{M}$. aeruginosa extract and MC-LR in photosynthesis or, instead, the low sensitivity of this parameter to evaluate more subtle biochemical alterations. Other putative downregulated processes assigned specifically to $13 \mathrm{1g} / \mathrm{L}$ MCLR treated plants are protein flavonoid biosynthesis, inositol, propanoate and nitrogen metabolism. Together, the results point to a decrease in the metabolism of rice, which may denote a putative toxic effect induced by $\mathrm{M}$. aeruginosa extract and MC-LR.

\section{Conclusions}

In this work it was observed that rice plants exposed to 0-78 1g/L MC-LR, during 2 and 7 days did not suffer major alterations in biomass and chlorophyll fluorescence. Moreover, the lack of variations in GST and GPx activities in plants challenged with M. aeruginosa extracts, suggests no major alterations in rice antioxidant mechanisms and the putative absence of oxidative stress. However, this assumption should be supported by additional data provided by alternative techniques to measure oxidative stress. The possible lack of sensitivity of the conventional parameters to measure toxicity was then covered with an investigation of the rice proteome. Proteomics analysis on

12-day-old plants exposed for 2 days to $M$. aeruginosa extracts (13-78 1g/L MC-LR) showed significant alterations in protein expression, with emphasis on protein folding and stress response members, energy, carbohydrate and nitrogen metabolism, and protein biosynthesis. The physiological implications associated to this metabolic outcome require further elucidation. Physiological and growth responses may be only registered by performing 
longer exposure experiments (chronic exposures).

\section{References}

Asensi M, Sastre J, Pallardo FV, Lloret A, Lehner M, Garcia de la Assuncion J (1999) Ration of reduced to oxidized glutathione as indicator of oxidative stress status and DNA damage. Method Enzymol 299:267-276. doi:10.1016/S0076-6879(99)99026-2

Baker NR, Rosenqvist E (2004) Applications of chlorophyll fluorescence can improve crop production strategies: an examination of future possibilities. J Exp Bot 55:1607-1621. doi:10.1093/jxb/ erh196

Bibo L, Yan G, Bangding X, Jiantong L, Yongding L (2008) A laboratory study on risk assessment of microcystin-RR in cropland. J Environ Manage 86:566-574. doi:10.1016/j.jenv man.2006.12.040

Bradford MM (1976) A rapid and sensitive method for the quantitation of microgram quantities of protein utilizing the principle of protein-dye binding. Anal Biochem 72:248-254. doi:10.1016/0003-2697(76)90527-3

Campos A, da Costa G, Coelho AV, Fevereiro P (2009) Identification of bacterial protein markers and enolase as a plant response protein in the infection of Olea europaea subsp.europaea by Pseudomonas savastanoi pv. savastanoi. Eur J Plant Pathol 125:603-616. doi:10.1007/s10658-009-9509-0

Campos A, Puerto M, Prieto A, Cameán A, Almeida AM, Coelho AV, Vasconcelos V (2012) Protein extraction and two-dimensional gel electrophoresis of proteins in the marine mussel Mytilus galloprovincialis: an important tool for protein expression studies, food quality and safety assessment. J Sci Food Agric 93:1779-1787. doi:10.1002/jsfa.5977

Campos A, Araújo P, Pinheiro C, Azevedo J, Osório H, Vasconcelos V (2013) Effects on growth, antioxidant enzyme activity and levels of extracellular proteins in the green alga Chlorella vulgaris exposed to crude cyanobacterial extracts and pure microcystin and cylindrospermopsin. Ecotox Environ Saf 94:45-53. doi:10.1016/j. ecoenv.2013.04.019

Chen J, Song L, Dai J, Gan N, Zhili L (2004) Effects of microcystins on the growth and the activity of superoxide dismutase and peroxidade of rape (Brassica napus L.) and rice (Oryza sativa L.). Toxicon 43:393-400. doi:10.1016/j.toxicon.2004.01.011

Chen J, Han FX, Wang F, Haiqiang Z, Shi Z (2012) Accumulation and phytotoxicity of microcystin-LR in rice (Oryza sativa). Ecotox Environ Saf 76:193-199. doi:10.1016/j.ecoenv.2011.09. 022

Crush JR, Briggs LR, Sprosen JM, Nichols SN (2008) Effect of irrigation with lake water containing microcystins on microcystin content and growth of ryegrass, clover, rape, and lettuce. Environ Toxicol 23:246-252. doi:10.1002/tox.20331

Dawson RM (1998) The toxicology of microcystins. Toxicon 36:953-962. doi:10.1016/S0041-0101(97)00102-5

El Khalloufi F, Oufdou K, Lahrouni M, El Ghazali I, Saqrane S, Vasconcelos V, Oudra B (2011) Allelopatic effects of cyanobacteria extracts containing microcystins on Medicago sativaRhizobia symbiosis. Ecotox Environ Saf 74(431):438. doi:10. 1016/j.ecoenv

El Khalloufi F, El Ghazali I, Saqrana S, Oufdou K, Vasconcelos V, Oudra B (2012) Phytotoxic effects of a natural bloom extract containing microcystons on Lycopersicon esculentum. Ecotox Environ Saf 79:199-205. doi:10.1016/j.ecoenv.2012.01.002

Eshdat Y, Holland D, Faltin Z, Ben-Hayyim G (1997) Plant glutathione peroxidases. Physiol Plant 100:234-240. doi:10. 1111/j.1399-3054.1997.tb04779.x

Faltin Z, Holland D, Velcheva M, Tsapovestky M, Roeckel-Drevet P, Handa AK, Mohamad A-A, Friedman-Einat M, Eshdat Y, Perl A (2010) Glutathione peroxidase regulation of reactive oxygen species level is crucial for in vitro plant differentiation. Plant Cell Physiol 51:1151-1162. doi:10.1093/pcp/pcq082

Flohé L, Gunzler WA (1984) Assays of glutathione peroxidase. Method Enzimol 105:114-121

Gobom J, Nordhoff E, Mirgorodskaya E, Ekman R, Roepstorff P (1999) Sample purification and preparation technique based on nano-scale reversed-phase columns for the sensitive analysis of complex peptide mixtures by matrix-assisted laser desorption/ ionization mass spectrometry. J Mass Spectrom 34:105-116. doi:10.1002/(SICI)1096-9888(199902)34:2 V05:AIDJMS768 [3.0.CO;2-4

Gomes C, Almeida A, Ferreira JA, Silva L, Santos-Sousa H, Pinto-deSousa J, Santos LL, Amado F, Schwientek T, Levery SB, Mandel U, Clausen H, David L, Reis CA, Osório H (2013) Glycoproteomic analysis of serum from patients with gastric precancerous lesions. J Proteome Res 12:1454-1466. doi:10. 1021/pr301112x

Habig W, Pabst MJ, Jakoby WB (1974) Glutathione S-transferases, the first enzymatic step in mercapturic acid formation. J Biol Chem 249:7130-7139

Heinemeyer J, Lewejohann D, Braun HP (2007) Blue-native gel electrophoresis for the characterization of protein complexes in plants. Methods Mol Biol 335:343-352. doi:10.1385/1-59745227-0:343

Hitzfeld BC, Hoger SJ, Dietrich DR (2000) Cyanobacterial toxins: removal during drinking water treatment, and human risk assessment. Environ Health Perspect 108:113-122

Ibelings BW, Chorus I (2007) Accumulation of cyanobacterial toxins in freshwater "seafood" and its consequences for public health: a review. Environ Pollut 150:177-192. doi:10.1016/j.envpol. 2007.04.012

Jámbrik K, Máthé C, Vasas G, Beyer D, Molnár E, Borbély G, M-Hamvas M (2011) Microcystin-LR induces chromatin alterations and modulates neutral single-strand-preferring nuclease activity in Phragmites australis. J Plant Physiol 168:678-686. doi:10.1016/j.jplph.2010.10.007

Kótai J (1972) Instructions for preparation of modified nutrient solution Z8 for algae. Norwegian Institute for Water Research, Oslo

Lahrouni M, Oufdou K, Faghire M, Peix A, El Khalloufi F, Vasconcelos V, Oudra B (2012) Cyanobacterial extracts containing microcystins affect the growth, nodulation process and nitrogen uptake of faba bean (Vicia faba L., Fabaceae). Ecotoxicology 21:681-687. doi:10.1007/s10646-011-0826-7

Lambert TW, Boland MP, Holmes CFB, Hrudey SE (1994) Quantitation of the Microcystin hepatotoxins in water at environmentally relevant concentrations with the Protein Phosphatase Bioassay. Environ Sci Technol 28:753-755. doi:10.1021/ es00053a032

Lawrence RA, Burk RF (1976) Glutathione peroxidase activity in selenium-deficient rat liver. Biochem Biophys Res Commun 71:952-958. doi:10.1016/0006-291X(76)90747-6

Lee R, Britz-McKibbin P (2009) Differential rates of glutathione oxidation for assessment of cellular redox status and antioxidant capacity by capillary electrophoresis-mass spectrometry: an elusive biomarker of oxidative stress. Anal Chem 81:7047-7056. doi:10. $1021 / \mathrm{ac} 901174 \mathrm{~g}$

Lee J-J, Jo H-J, Kong K-H (2011) A plant-specific Tau class glutathione S-transferase from Oryza sativa having significant detoxification activity towards chloroacetanilide herbicides. Bull Korean Chem Soc 32:3756-3759. doi:10.1016/j.pestbp.2011.10. 005

Levison BS, Zhang R, Wang Z, Fu X, DiDonato JA, Hazen SL (2013) Quantification of fatty acid oxidation products using online highperformance liquid chromatography tandem mass spectrometry. Free Radic Biol Med 59:2-13. doi:10.1016/j.freeradbiomed. 2013.03.001

Marrs KA (1996) The functions and regulation of glutathione 
S-transferases in plants. Annu Rev Plant Physiol Plant Mol Biol 47:127-158. doi:10.1146/annurev.arplant.47.1.127

Máthé C, Beyer D, Erdodi F, Serfozo Z, Székyölgyi L, Vasas G, M-Hamyas M, Jámbrik K, Gonda S, Kiss A, Szigeti ZM, Surányi G (2009) Microcystin-LR induces abnormal root development by altering microtubuleorganization in tissue-cultured common reed (Phragmites australis) plantlets. Aquat Toxicol 92:122-130. doi:10.1016/j.aquatox.2009.02.005

Maxwell K, Johnson N (2000) Chlorophyll fluorescence - a practical guide. J Exp Bot 51:659-668. doi:10.1093/jexbot/51.345.659

Miao Y, Lv D, Wang P, Wang X-C, Chen J, Miao C, Song C-P (2006) An arabidopsis glutathione peroxidase functions as both a redox transducer and a scavenger in abscisic acid and drought stress responses. Plant Cell 18:2749-2766. doi:10.1105/tpc.106. 044230

Miché L, Balandreau J (2001) Effects of rice seed surface sterilization with hypochlorite on inoculated Burkholderia vietnamiensis. Appl Environ Microbiol 67:3046-3052. doi:10.1128/AEM.67.7. 3046- 3052.2001

Navrot N, Collin V, Gualberto J, Gelhaye E, Hirasawa M, Rey P, Knaff DB, Isaakidis E, Jacquot J-P, Rouhier N (2006) Plant glutathione peroxidases are functional peroxiredoxins distributed in several subcellular compartments and regulated during biotic and abiotic stresses. Plant Physiol 142:1364-1379. doi:10.1104/ pp.106.089458

Neuhoff V, Arnold N, Taube D, Ehrhardt W (1988) Improved staining of proteins in polyacrylamide gels including isoelectric focusing gels with clear background at nanogram sensitivity using Coomassie Brilliant Blue G-250 and R-250. Electropho- resis 9:255-262. doi:10.1002/elps.1150090603

Oh H-M, Lee SJ, Kim J-H, Kim H-S, Yoon B-D (2001) Seasonal variation and indirect monitoring of microcystin concentrations in Daechung reservoir, Korea. Appl Environ Microbiol 67:1484-1489. doi:10.1128/AEM.67.4.1484-1489.2001

Perkins DN, Pappin Dj, Creasy DM, Cottrell JS (1999) Probabilitybased protein identification by searching sequence databases using mass spectrometry data. Electrophoresis 20:3551-3567. doi:10.1002/(SICI)1522-2683(19991201)20

Peuthert A, Chakrabarti S, Pflugmacher S (2007) Uptake of microcystins-LR and -LF (cyanobacterial toxins) in seedlings of several important agricultural plant species and the correlation with cellular damage (lipid peroxidation). Environ Toxicol 22(436):442. doi:10.1002/tox.20266

Peuthert A, Lawton L, Pflugmacher S (2008) In vivo influence of cyanobacterial toxins on enzyme activity and gene expression of protein phosphatases in Alfalfa (Medicago sativa). Toxicon 52:84-90. doi:10.1016/j.toxicon.2008.04.172

Pflugmacher S (2004) Promotion of oxidative stress in the aquatic macrophyte Ceratophyllum demersum during biotransformation of the cyanobacterial toxin Microcystin-LR. Aquat Toxicol
70:169-178. doi:10.1016/j.aquatox.2004.06.010

Pflugmacher S, Aulhorn M, Grimm B (2007) Influence of a cyanobacterial crude extract containing microcystin-LR on the physiology and antioxidative defence systems of different spinach variants. New Phytol 175:482-489. doi:10.1111/j. 1469-8137.2007.02144.x

Pinheiro C, Azevedo J, Campos A, Loureiro S, Vasconcelos V (2013) Absence of negative allelopathic effects of cylindrospermopsin and microcystin-LR on selected marine and freshwater phytoplankton species. Hydrobiologia 705:27-42. doi:10.1007/ s10750012-1372-x

Prieto A, Campos A, Cameán A, Vasconcelos V (2011) Effects on growth and oxidative stress status of rice plants (Oryza sativa) exposed to two extracts of toxin-producing cyanobacteria (Aphanizomenon ovalisporum and Microcystis aeruginosa). Ecotoxicology and Enviromental Safety 74:1973-1980. doi:10. 1016/j.ecoenv.2011.06.009

Ramanan S, Tang J, Velayudhan A (2000) Isolation and preparative purification of microcystin variants. J Chromatogr A 883:103-112. doi:10.1016/S0021-9673(00)00378-2

Rivasseau C, Racaud P, Deguin A, Hennion M-C (1999) Development of a bioanalytical phosphatase inhibition test for the monitoring of microcystins in environmental water samples. Anal Chim Acta 394:243-257. doi:10.1016/S0003-2670(99)00301-3

Saker ML, Fastner J, Dittmann E, Christiansen G, Vasconcelos VM (2005) Variation between strains of the cyanobacterium Microcystis aeruginosa isolated from a Portuguese river. J Appl Microbiol 99:749-757. doi:10.1111/j.1365-2672.2005.02687.x

Saqrane S, El Ghazali I, Ouahid Y, El Hassni M, El Hadrami I, Bouarad L, del Campo FF, Oudra B, Vasconcelos V (2007) Phytotoxic effects of cyanobacteria extract on the aquatic plant Lemna gibba: microcystin accumulation, detoxication and oxidative stress induction. Aquat Toxicol 83:284-294. doi:10. 1016/j.aquatox.2007.05.004

Saqrane S, Ghazali IE, Oudra B, Bouarab L, Vasconcelos V (2008) Effects of cyanobacteria producing microcystins on seed germination and seedling growth of several agricultural plants. $\mathbf{J}$ Environ Sci Health, Part B 43:443-451. doi:10.1080/ 10934520701796192

Saqrane S, Ouahid Y, El Ghazali I, Oudra B, Bouarab L, del Campo FF (2009) Physiological changes in Triticum durum, Zea mays, Pisum sativum and Lens esculenta cultivars, caused by irrigation with water contaminated with microcystins: a laboratory experimental approach. Toxicon 53:786-796. doi:10.1016/j.toxicon. 2009.01.028

Sivonen K, Jones G, Chorus I, Bartram J (1999) Toxic cyanobacteria in water: a guide to their public health consequences, monitoring and management. E\&FN Spon, London

Tyler AN, Hunter PD, Carvalho L, Codd GA, Elliott JA, Ferguson CA, Hanley ND, Hopkins DW, Maberly SC, Mearns KJ, Scott 
EM (2009) Strategies for monitoring and managing mass populations of toxic cyanobacteria in recreational waters: a multi-interdisciplinary approach. Environ Health 8:S11. doi:10. 1186/1476-069X-8-S1-S11

van Apeldoorn ME, van Egmond HP, Speijers GJA, Bakker GJI (2007) Toxins of cyanobacteria. Mol Nutr Food Res. doi:10. 1002/mnfr.200600185

Vinagre C, Madeira D, Narciso L, Cabral HN, Diniz M (2012) Effect of temperature on oxidative stress in fish: lipid peroxidation and catalase activity in the muscle of juvenile seabass, Dicentrarchus labrax. Ecol Indic 23:274-279. doi:10.1016/j.ecolind.2012.04. 009

Wang W, Vinocur B, Shoseyov O, Altman A (2004) Role of plant heat-shock proteins and molecular chaperones in the abiotic stress response. Trends Plant Sci 9:244-252. doi:10.1016/j. tplants.2004.03.006

WHO (2003) Cyanobacterial toxins: Microcystin-LR in drinkingwater. Background document for preparation of WHO Guidelines for drinking-water quality. World Health Organization. http:// www.who.int/water_sanitation_health/dwq/en/gdwq3_12.pdf Accessed 14 May 2011

Xiao FG, Zhao XL, Tang J, Gu XH, Zhang JP, Niu WM (2009) Necessity of screening water chestnuts for microcystins after cyanobacterial blooms break out. Arch Environ Contam Toxicol 57:256-263. doi:10.1007/s00244-008-9275-6

Yin L, Huang J, Li D, Liu Y (2005) Microcystin-RR uptake and its effects on the growth of submerged macrophyte Vallisneria natans (lour.). Environ Toxicol 20:308-313. doi:10.1002/tox. 20122

Yoshida S, Forno DA, Cock JH, Gomez KA (1976) Laboratory manual for physiological studies of rice, 3rd edn. IRRI, Manila, pp 61-66

Zhang H-j, Zhang J-y, Hong Y, Chen Y-x (2007) Evaluation of organ distribution of microcystins in the freshwater phytoplanktivorous fish Hypophthalmichthys molitrix. J Zhejiang Univ Sci B 8:116-120. doi:10.1631/jzus.2007.B0116 

